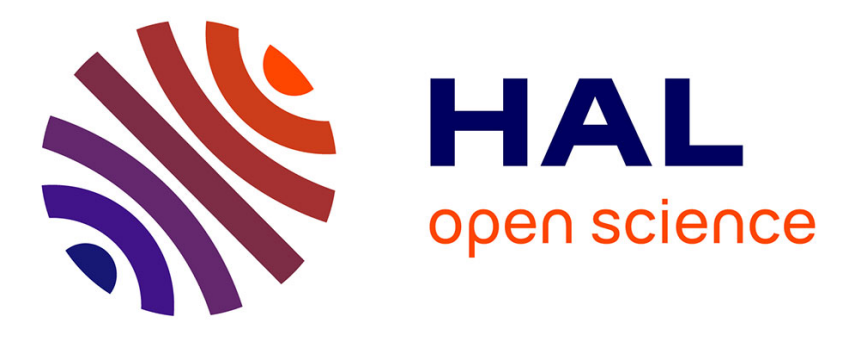

\title{
Specificity of transcription enhancement via the STAT responsive element in the serine protease inhibitor 2.1 promoter
}

Timothy J.J Wood, Daniel Sliva, Peter Lobie, Fabrice Goullieux, Alice Mui, Bernd Groner, Gunnar Norstedt, Lars-Arne Haldosén

\section{To cite this version:}

Timothy J.J Wood, Daniel Sliva, Peter Lobie, Fabrice Goullieux, Alice Mui, et al.. Specificity of transcription enhancement via the STAT responsive element in the serine protease inhibitor 2.1 promoter. Molecular and Cellular Endocrinology, 1997, 130 (1-2), pp.69-81. 10.1016/s0303-7207(97)00075-0 . hal-02427422

\section{HAL Id: hal-02427422 \\ https:/ /hal-univ-tours.archives-ouvertes.fr/hal-02427422}

Submitted on 4 Nov 2021

HAL is a multi-disciplinary open access archive for the deposit and dissemination of scientific research documents, whether they are published or not. The documents may come from teaching and research institutions in France or abroad, or from public or private research centers.
L'archive ouverte pluridisciplinaire HAL, est destinée au dépôt et à la diffusion de documents scientifiques de niveau recherche, publiés ou non, émanant des établissements d'enseignement et de recherche français ou étrangers, des laboratoires publics ou privés. 


\title{
Specificity of transcription enhancement via the STAT responsive element in the serine protease inhibitor 2.1 promoter
}

\author{
Timothy J.J. Wood ${ }^{\mathrm{a}, \mathrm{b}, *}$, Daniel Sliva ${ }^{\mathrm{a}}$, Peter E. Lobie ${ }^{\mathrm{a}}$, Fabrice Goullieux ${ }^{\mathrm{c}}$, Alice L. Mui ${ }^{\mathrm{d}}$, \\ Bernd Groner ${ }^{\mathrm{c}}$, Gunnar Norstedt ${ }^{\mathrm{a}, \mathrm{b}}$, Lars-Arne Haldosén ${ }^{\mathrm{a}}$ \\ ${ }^{a}$ Department of Medical Nutrition, Karolinska Institute, Novum, S-141 86 Huddinge, Sweden \\ ${ }^{\mathrm{b}}$ Department of Cell Biology, Pharmacia and Upjohn, Strandbergsgatan 49, S-112 87 Stockholm, Sweden \\ ${ }^{\mathrm{C}}$ Institute for Experimental Cancer Research, Tumour Biology Center, Breisacher Strasse 117, D 79106 Freiburg, Germany \\ d DNAX Research Institute, 901 California Avenue, Palo Alto, CA 94304, USA
}

Received 27 November 1996; received in revised form 26 February 1997; accepted 26 March 1997

\begin{abstract}
The growth hormone regulated serine protease inhibitor (SPI) 2.1 and 2.2 gene promoters have been shown to contain a response element similar to the $\gamma$-interferon activated sequence (GAS) family of signal transducer and activator of transcription (STAT) response elements. We have investigated the STAT and cytokine specificity of the SPI 2.1 STAT responsive element using a luciferase (LUC) reporter construct and a cDNA complementation strategy in the COS 7 cell line. Growth hormone was found to stimulate SPI-LUC reporter gene expression via activation of STAT 5, but not STATs 1 or 3, which indicates that the SPI 2.1 STAT responsive element is STAT 5 specific. In addition to the growth hormone receptor, the receptors for prolactin and erythropoietin enhanced gene transcription via the SPI 2.1 STAT responsive element, which indicates that this element is, on the other hand, not cytokine specific. Activation of STAT 5 was also observed after growth hormone treatment of cells transfected with cDNA expression plasmids for several different truncated growth hormone receptor mutants, although this activation was less efficient than with the wild type receptor. Point mutation of individual tyrosines in the growth hormone receptor intracellular domain to phenylalanines had no significant effect on signal transduction via STAT 5. These data, taken together with results from experiments using the phosphatase inhibitor sodium orthovanadate, suggest that STAT 5 may not have an absolute requirement for specific phosphorylated receptor tyrosine docking sites. That receptor tyrosine residues in a variety of amino acid contexts, or phosphorylated Janus kinase (JAK) 2 alone, can facilitate STAT 5 activation could explain the observed lack of cytokine specificity in STAT 5 activation. (C) 1997 Elsevier Science Ireland Ltd.
\end{abstract}

Keywords: Growth hormone; STAT 5; Cytokine

\section{Introduction}

It is well established that the growth hormone receptor associates with Janus kinase (JAK) 2 following ligand binding (Argetsinger et al., 1993; Frank et al., 1994; 1995). This property is shared with receptors for many other cytokines, such as prolactin, erythropoietin, thrombopoietin, several interleukins, and interferons $\alpha$

\footnotetext{
* Corresponding author. Tel.: + 468 6959134; fax: +468 6958042; e-mail: timothy.wood@eu.pnu.com
}

and $\gamma$ (Ihle and Kerr, 1995). Five unique JAKs have been identified; JAKs 1, 2 and 3, tyk 2 and the Drosophila hopscotch gene product (Ihle and Kerr, 1995). The JAKs (two faced) are characterised by their possession of both a consensus tyrosine kinase domain and a tyrosine kinase like domain. They lack src homology (SH) domains of type 2 or 3 which are often found in tyrosine kinases. The JAKs have been demonstrated to catalyse tyrosine phosphorylation of a variety of substrates including cytokine receptors (Silva et al., 1993) and members of the signal transducer and activa- 
tor of transcription (STAT) transcription factor family (Ihle and Kerr, 1995).

To date eight unique STATs have been identified: STAT $1 \alpha$ and its splice variant STAT $1 \beta$ (p91 and $\mathrm{p} 84$ respectively, (Schindler et al., 1992)) STAT 2 (pll3, (Fu et al., 1992)), epidermal growth factor and interleukin (IL)-6 activated STAT 3 (acute phase response factor, (Zhong et al., 1994; Wegenka et al., 1994; Akira et al., 1994)), STAT 4 (Yamamoto et al., 1994), interleukin-4 activated STAT 6 (IL 4 STAT, (Hou et al., 1994)), STAT 5 (mammary gland factor, (Wakao et al., 1994)), interleukin-1/interleukin-6/lipopolysacharide activated LIL-STAT (Tsukada et al., 1996) and a Drosophila STAT (Yan et al., 1996a,b). Two isoforms of STAT 5 have been identified (Liu et al., 1995).

The STAT molecule can be divided into five functional domains: a conserved amino terminal domain, the DNA binding domain, an SH 2 domain, a domain showing weak homology with the SH 3 domain and a variable carboxy terminal domain. The activation of STATs 3 and 6 has been shown to be facilitated by the presence of specific phosphorylated tyrosine residues in the intracellular domains of, respectively, the interleukin-6 and -4 receptors (Hou et al., 1994; Stahl et al., 1995). The phosphorylated receptor tyrosine residues may confer specificity on the activation of these STATs by acting as docking sites for the STAT SH 2 domain.

The expression of the closely related serine protease inhibitor (SPI) 2.1 and 2.2 genes is under strict hormonal control in rat liver and is totally repressed by hypophysectomy. Expression can be partially restored by growth hormone treatment (Le-Cam et al., 1987a; Le-Cam and Le-Cam, 1987b; Le-Cam et al., 1994). The SPI 2.1 and 2.2 gene promoters, which are virtually identical, both contain a $9 \mathrm{bp}$ element related to the interferon $\gamma$-activated sequence (GAS) family of STAT transcription factor response elements (Sliva et al., 1994; Berry et al., 1994). We have recently shown that this $9 \mathrm{bp}$ element, which we have designated SPI GAS like element (GLE) 1, can confer growth hormone responsiveness on the expression of an adjacent cDNA in reporter gene constructs (Wood et al., 1995).

In this study we have investigated the STAT and cytokine specificity of stimulation of gene expression via the STAT responsive element in the SPI 2.1 promoter. The results show that although the SPI 2.1 STAT responsive element is STAT 5 specific, a number of different cytokine receptors can stimulate gene transcription via this element. We suggest that the STAT 5 SH 2 domain may not show the high level of receptor tyrosine selectivity seen with other SH 2 domains; that several phosphorylated growth hormone receptor tyrosine residues may act as docking sites for STAT 5; and that JAK 2 may provide docking sites for STAT 5 in activated cytokine receptor-JAK 2 signalling complexes. This last hypothesis is supported by the observation that JAK 2 and STAT 5 form a stable complex in the absence of ligand activated receptors in cells treated with the phosphatase inhibitor sodium orthovanadate.

\section{Materials and methods}

\subsection{Cell culture}

COS 7 cells were cultured at $37^{\circ} \mathrm{C}$ under $5 \% \mathrm{CO}_{2}$ in Dulbecco's modified Eagle's medium (DMEM, Life Technologies) containing 10\% foetal calf serum (Life Technologies) and $50 \mathrm{U} / \mathrm{ml}$ penicillin $/ 50 \mu \mathrm{g} / \mathrm{ml}$ streptomycin (Life Technologies). Growth of COS 7 cells to confluency was avoided in order to prevent syncytia formation.

\subsection{Reporter plasmids}

Six copies of the SPI-GHRE $(-175$ and -114 in the SPI 2.1 promoter (Sliva et al., 1994) DNA element GATCTACGCTTCTACTAATCCATGTTCTGAGAAATCATCCAGTCTGCCCATG (previously described (Wood et al., 1995) GAS like elements underscored) were fused to a minimal thymidine kinase (TK) promoter $(-104$ to +51$)$ derived from pBLCAT2 and inserted upstream of the luciferase cDNA in pGL2 basic (Promega) to generate the pSPI-LUC reporter plasmid (SPI-LUC luciferase reporter gene). The pB2WT2 luciferase reporter plasmid contains two IRF1 GAS like elements (TTCCCCGAA) fused to a minimal TK promoter, to give the IRF-1 LUC reporter gene).

\section{3. cDNA expression plasmids}

The wild type and mutated rat growth hormone receptor cDNAs were expressed using vectors (phMThGH derived) containing the human metallothionein promoter. Premature stop codons or tyrosine to phenylalanine mutations were introduced by site directed mutagenesis. The mouse prolactin receptor cDNA was expressed using a vector (pCMV5 derived) containing the CMV promoter. The mouse erythropoietin receptor and sheep STAT 5 cDNAs were expressed using vectors (pXM derived) containing the AdMLP promoter. The mouse STAT 1 and STAT 3 cDNAs were expressed using vectors (pME18S derived) containing the $\operatorname{SR} \alpha$ promoter. pRc-CMV-CAT (Invitrogen) was used for chloramphenicol acetyl transferase (CAT) normalisation of transfection efficiencies. The expression of all cDNAs was tested either by binding assay (receptors) or Western blotting (STATs). 
2.4. Cell transfection and luciferase and chloramphenicol acetyl transferase assays

Cells, $5 \times 10^{5}$, were seeded in $30 \mathrm{~mm}$, cell culture dishes, grown to $80 \%$ confluency and then washed twice with phosphate buffered saline (PBS). Transfections were carried out in serum free DMEM with $2.5 \mu \mathrm{g}$ $\mathrm{CsCl}$ purified plasmid DNA and $7.5 \mu \mathrm{l} /$ dish Transfection Reagent (DOTAP, Boehringer Mannheim) according to the manufacturer's instructions. Cells were incubated with DOTAP/DNA for an initial $12 \mathrm{~h}$ and then serum free media containing $100 \mathrm{nM}$ hGH (Pharmacia), $4 \mathrm{U} / \mathrm{ml}$ mouse erythropoietin (Boehringer Mannheim) or $1 \mathrm{mM}$ sodium orthovanadate, as appropriate, for a further $24 \mathrm{~h}$. The cells were then washed with PBS and scraped into $120 \mu 1$ of lysis buffer containing $25 \mathrm{mM}$ Tris-phosphate, $\mathrm{pH} 7.8,2 \mathrm{mM}$ DTT, $2 \mathrm{mM}$ 1,2 diaminocyclohexane $N, N, N^{\prime}, N^{\prime}$ tetraacetic acid, $10 \%$ glycerol and 1\% Triton X-100. Luciferase activity was measured using $30 \mu \mathrm{g}$ of cell extract dissolved in $300 \mu 1$ of buffer containing $0.12 \mathrm{mg} / \mathrm{ml}$ D-luciferin (Sigma), $10 \mathrm{mM}$ DTT, $1 \mathrm{mg} / \mathrm{ml}$ bovine serum albumin (BSA), $10 \mathrm{mM} \mathrm{Mg-acetate,} 0.1 \mathrm{M}$ Tris-acetate, $\mathrm{pH}$ 7.75, $2 \mathrm{mM}$ EDTA, $0.5 \mathrm{mM}$ ATP and $0.05 \mathrm{mM}$ sodium pyrophosphate. Luminescence was monitored for $10 \mathrm{~s}$ using a Wallac microbeta counter. A plasmid constitutively expressing CAT was used as a co-transfected normalising control in luciferase reporter experiments. CAT activity was measured in 96 well ELISA plates using a microdiffusion assay. Twenty microgrammes of protein extract in $100 \mu 1$ of $0.15 \mathrm{M}$ Tris $-\mathrm{HCl}, \mathrm{pH} 8.0$ containing $1 \mathrm{mM}$ chloramphenicol and $2 \mu \mathrm{l}(0.1 \mu \mathrm{Ci}, 200 \mathrm{mCi} / \mathrm{mmol})\left[{ }^{3} \mathrm{H}\right]$ butyryl coenzyme A (Amersham) was covered with $100 \mu 1 \beta$-plate Scint scintillation fluid and incubated at $65^{\circ} \mathrm{C}$ for $3 \mathrm{~h}$. The diffusion of $\left[{ }^{3} \mathrm{H}\right]$ butyrylated chloramphenicol into the organic scintillant was detected using a Wallac microbeta counter.

\subsection{Western blotting of STATS}

Cells, $5 \times 10^{5}$, were seeded in $30 \mathrm{~mm}$, cell culture dishes, grown to $80 \%$ confluency and then washed twice with PBS. Transfections were carried out in serum free DMEM with $2.5 \mu \mathrm{g}$ CsCl purified cDNA expression plasmid for mouse STAT 1, mouse STAT 3 or sheep STAT 5 and $7.5 \mu 1 /$ dish Transfection Reagent (DOTAP, Boehringer Mannheim) according to the manufacturer's instructions. Cells were incubated with DOTAP/DNA for an initial $12 \mathrm{~h}$ and then serum free media for a further $12 \mathrm{~h}$. The cells were then washed with PBS and scraped into $120 \mu 1$ SDS-polyacrylamide gel electrophoresis (SDS-PAGE) loading buffer. The lysate was separated by $8 \%$ SDS-PAGE transferred to nitrocellulose membrane (Amersham) and the expression levels of STATs 1,3 and 5 were examined by
Western blotting using specific monoclonal anti STAT 1, 3 and 5 antibodies (Tranduction Laboratories, raised against peptides corresponding to amino acids 592 $731,1-175$ and $451-649$ of respectively human STAT 1, rat STAT 3 and sheep STAT 5) at a dilution of $1: 1000$. Binding of primary antibodies was visualised using horseradish peroxidase conjugated secondary antibodies (Sigma) diluted 1:1000 and the enhanced chemiluminescence detection system (Amersham) following the manufacturer's protocol.

\subsection{Growth hormone binding assay}

Cells, $5 \times 10^{5}$, were seeded in $30 \mathrm{~mm}$, cell culture dishes, grown to $80 \%$ confluency and then washed twice with PBS. Transfections were carried out in serum free DMEM with $2.5 \mu \mathrm{g} \mathrm{CsCl}$ purified growth hormone receptor cDNA expression plasmid and $7.5 \mu \mathrm{l} /$ dish Transfection Reagent (DOTAP, Boehringer Mannheim) according to the manufacturer's instructions. Cells were incubated with DOTAP/DNA for an initial $12 \mathrm{~h}$ and then serum free media for a further 12 h. The cells were then washed with PBS and $\sim 100000$ $\mathrm{cpm}{ }^{125}$ I-labelled human growth hormone was added in the presence or absence of an excess $(1000 \mathrm{nM})$ unlabelled hormone. Following incubation at $37^{\circ} \mathrm{C}$ for $2 \mathrm{~h}$ the cells were washed three times with PBS, lysed in $1 \%$ $\mathrm{SDS} / 0.5 \mathrm{~m} \mathrm{NaOH}$ and radioactivity was measured using a Wallac $\gamma$-radiation counter.

\subsection{Immunoprecipitation and Western blotting analysis}

Cells, $1 \times 10^{6}$, were seeded in $75 \mathrm{~cm}^{2}$, cell culture flasks, grown to $80 \%$ confluency and then washed twice with PBS. Transfections were carried out in serum free DMEM with $2.5 \mu \mathrm{g} \mathrm{CsCl}$ purified cDNA expression plasmid for HA (influenza hemagglutin A) epitope tagged sheep STAT 5 cDNA and $7.5 \mu \mathrm{l} /$ dish Transfection Reagent (DOTAP, Boehringer Mannheim) according to the manufacturer's instructions. Cells were incubated with DOTAP/DNA for an initial $12 \mathrm{~h}$ and then treated with vehicle or $1 \mathrm{mM}$ sodium orthovanadate for a further $4 \mathrm{~h}$. Following cell lysis in hypotonic buffer whole cell extracts $(100 \mu \mathrm{g}$ protein $)$ were immunoprecipitated overnight at $4^{\circ} \mathrm{C}$ with $5 \mu 1$ antibody against the HA epitope (12CA5, Babco) in $20 \mathrm{mM}$ Tris $-\mathrm{HCl} \mathrm{pH} 7.4,20 \mathrm{mM} \mathrm{MgCl}_{2}$, and $0.1 \%$ BSA. Immunocomplexes were isolated on Protein $\mathrm{G}$ coupled Sepharose, resolved on 7.5\% SDS-PAGE and electrophoretically transferred to PVDF membrane (Millipore). Western blotting was performed with specific mouse JAK 1 antibodies, (directed against the peptide KTLIEKERFYSRCRPVTPSC from human JAK 1), and specific mouse JAK 2 antibodies (Upstate Biotechnology, raised against a peptide corresponding to amino acid residues 758-776) both diluted 1:1000. 
Binding of primary antibodies was visualised using horseradish peroxidase conjugated secondary antibodies (Sigma) diluted 1:1000 and the enhanced chemiluminescence detection method (Amersham) following the manufacturer's protocol.

\section{Results}

\subsection{Growth hormone dependent activation of gene expression via the SPI 2.1 STAT responsive element}

A STAT responsive element present in the serine protease inhibitor 2.1 growth hormone responsive enhancer element (SPI-GLE 1, (Wood et al., 1995)) has been shown to bind STAT 5 in gel mobility shift assays with nuclear extracts from several cell lines and rat liver (Wood et al., 1995). It has also been shown to mediate the stimulatory effect of STAT 5 on gene transcription (Wood et al., 1995). STATs 1 and 3 are absent from the SPI STAT responsive element binding complexes isolated from rat liver (Thomas et al., 1995). Growth hormone has, however, been shown to activate these STATs in other cell types (Meyer et al., 1994; Finbloom et al., 1994; Gronowski and Rotwein, 1994; Smit et al., 1996) and it is probable that these STATs are activated by other cytokines in liver. In order to determine whether the STAT responsive element is STAT 5 specific, a cDNA expression vector for the rat growth hormone receptor was transfected into COS 7 cells together with cDNA expression plasmids for STATs 1, 3 or 5 and the pSPI-LUC reporter plasmid. A reporter plasmid containing a $\sim 50$ bp region of the SPI 2.1 promoter, rather than the SPI-GLE 1 element alone, was chosen for these experiments in order to take into account the modulating effects of sequences adjacent to SPI GLE 1. As can be seen in Fig. 1 cells transfected with STAT 5 cDNA showed a growth hormone dependent stimulation of reporter gene expression. No such effect was seen in cells transfected with STAT 1 or STAT 3 cDNA. The plasmids were transfected in the molar ratio 1:1:2 (receptor:STAT:reporter). Molar equivalent (0.1) pRc-CMV-CAT was included in each transfection for normalisation. The luciferase induction obtained with STAT 5 showed a 'bell shaped' dose response for growth hormone treatment (Fig. 2). This is characteristic of a system in which signalling is initiated by receptor homodimerisation induced by a ligand with different affinities for the two receptor chains. Nuclear extracts from COS 7 cells transfected as in Fig. 1 were also subjected to gel electrophoresis mobility shift assays using a radioactively labelled probe corresponding to the SPI-GLE 1. The pattern of DNA binding observed was identical to the pattern of transcription activation shown in Fig. 1 (data not shown).
Although the STAT 1 and 3 expression plasmids produced immunologically reactive protein as judged by Western blotting of extracts from transfected COS 7 cells (Fig. 3), one interpretation of the results shown in Fig. 1 is that these proteins were non-functional. A variety of cytokines including prolactin, interleukins-2 and 6 and interferon $\gamma$ stimulate gene transcription via a GAS like element in the interferon regulatory factor-1 (IRF-1) gene promoter (Yuan et al., 1994; Schwarz et al., 1992; O’Neal and Lee, 1994). In addition, several STATs have been shown to bind to the IRF-1 GAS like element in gel electrophoresis mobility shift assays which indicates that this element responds to a broad range of STATs. An expression plasmid for the rat growth hormone receptor was therefore transfected into COS 7 cells together with expression plasmids for STATs 1,3 or 5 and the pB2WT2 luciferase reporter plasmid which contains the IRF-1-LUC reporter gene. The plasmids were transfected in the ratio 1:1:3 (receptor:STAT:reporter). Molar equivalent (0.1) pRc-CMVCAT was included in each transfection for normalisation.

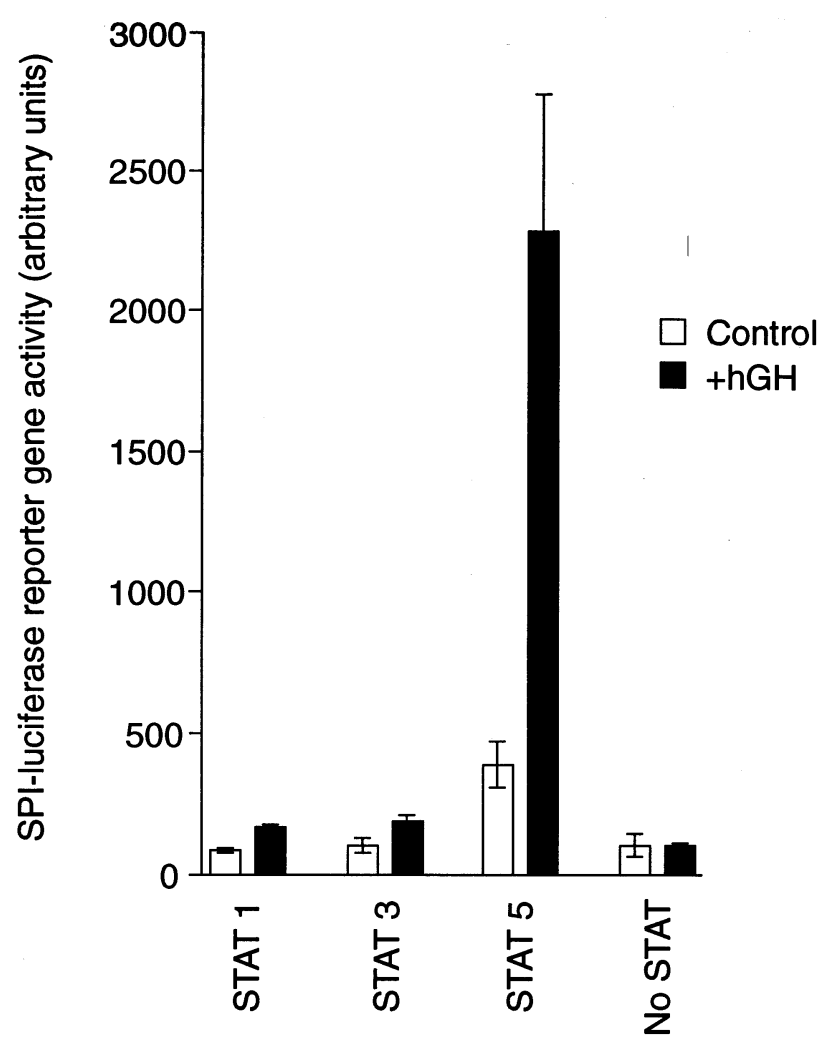

Fig. 1. COS 7 cells were transfected with the pSPI-LUC luciferase reporter plasmid, pRc-CMV-CAT normalisation control plasmid, a cDNA expression plasmid for the rat growth hormone receptor and cDNA expression plasmids for mouse STAT 1, mouse STAT 3 or sheep STAT 5. The cells were treated, as indicated, with $100 \mathrm{nM}$ human growth hormone for $24 \mathrm{~h}$ and then harvested for reporter gene assays. Values shown represent normalised luciferase activities in arbitrary units. Each column represents the average of three independent experiments. Error bars represent S.D. 


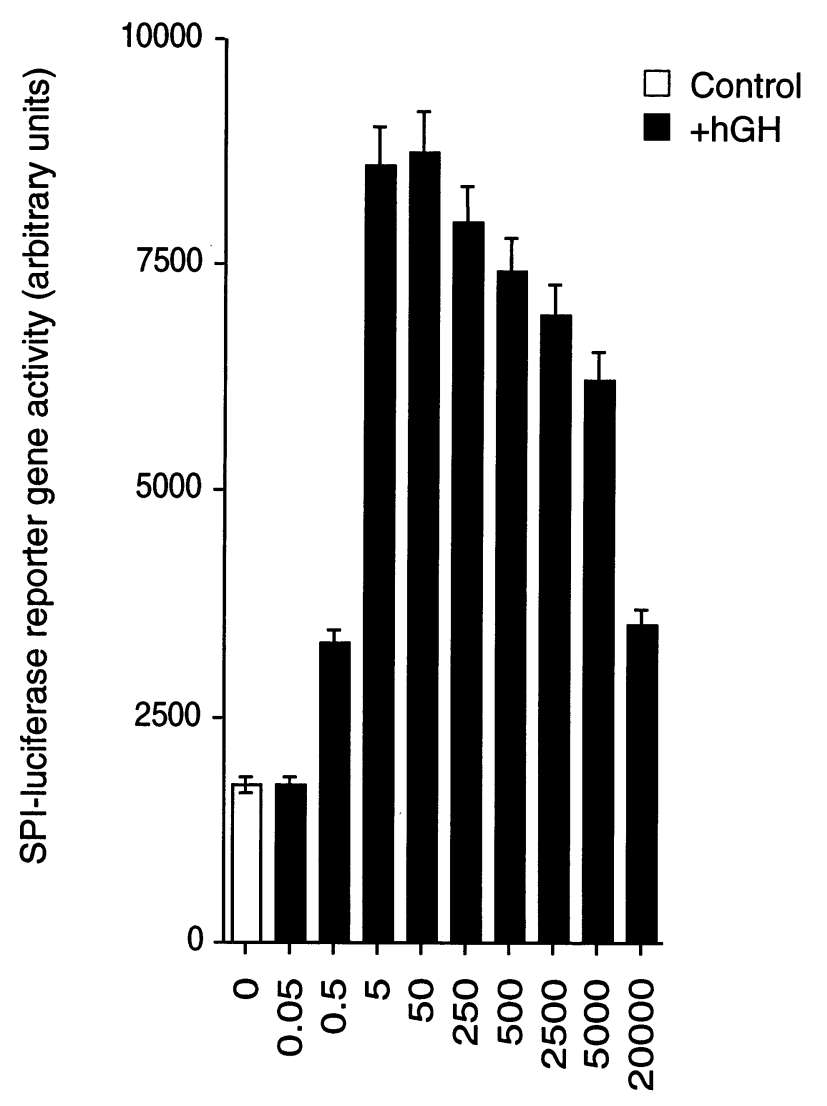

nM hGH

Fig. 2. COS 7 cells were transfected with the pSPI-LUC luciferase reporter plasmid, pRc-CMV-CAT normalisation control plasmid, and cDNA expression plasmids for the rat growth hormone receptor and STAT 5. The cells were treated, as indicated, with human growth hormone for $24 \mathrm{~h}$ and then harvested for reporter gene assays. Values shown represent normalised luciferase activities in arbitrary units. Each column represents the average of three independent experiments. Error bars represent S.D.

As can be seen in Fig. 4 the IRF-1-LUC reporter gene, unlike the SPI-LUC reporter gene, was activated, albeit weakly, by growth hormone treatment of cells in the absence of transfected STAT cDNA. Gel mobility 'super' shift assays using specific antibodies indicated that the endogenous STAT activity present in COS 7 cells is STAT 1 like (Sliva et al., unpublished observation). Transfection of STAT 1 cDNA had only a small effect on reporter gene expression. This suggests that the expression level of STAT 1 in COS 7 cells is not limiting for growth hormone receptor mediated stimulation of gene expression via STAT 1. Transfection of both STAT 5 and 3 cDNA clearly enhanced reporter gene expression confirming that both STAT 3 and STAT 5 can mediate growth hormone dependent gene transactivation in COS 7 cells expressing transfected cDNA. Interestingly both the background and growth hormone stimulated levels of reporter gene expression are increased by overexpression of STATs in COS 7 cells. This may be a result of autoactivation of the growth hormone receptor. The correlation between the level of cytokine receptor expression and the level of reporter gene background expression in unstimulated COS 7 cells supports this hypothesis (Wood et al., 1995 and Wood et al., unpublished observation). Alternatively it may be a result of background activation of STATs by other signal transduction pathways.

\subsection{Prolactin and erythropoietin dependent activation of gene expression via the SPI 2.1 STAT responsive element}

Both prolactin and erythropoietin have been shown to activate STAT 5 DNA binding in gel electrophoresis mobility shift assays. However, DNA binding of STATs in the sensitive gel mobility shift assay does not necessarily correlate with activation of transcription. It was therefore considered interesting to determine whether activation of STAT 5 DNA binding by these cytokines is reflected in stimulation of expression of the SPI-LUC reporter gene. cDNA expression vectors for mouse prolactin or mouse erythropoietin receptors were therefore transfected into COS 7 cells together with expression plasmids for STATs 1,3 or 5 and the pSPI-LUC reporter plasmid. As can be seen in Fig. 5 the expression of SPI-LUC reporter gene was greatly increased by ligand activation of both prolactin and erythropoietin receptors, but only in cells expressing STAT 5. This indicates that although stimulation of gene expression via the SPI 2.1 STAT responsive element is STAT 5 specific it is not cytokine specific.

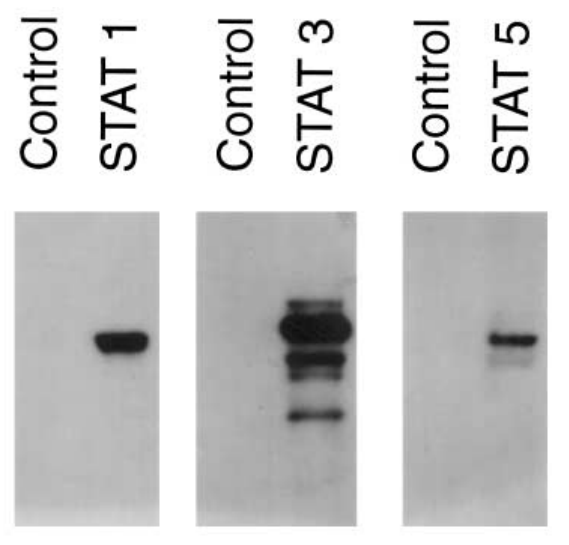

Fig. 3. COS 7 cells were transfected with cDNA expression plasmids for mouse STAT 1, mouse STAT 3 or sheep STAT 5. After $12 \mathrm{~h}$ cells were harvested and the expression levels of STATs 1, 3 and 5 examined by Western blotting. Extracts from untransfected cells are shown for reference. 


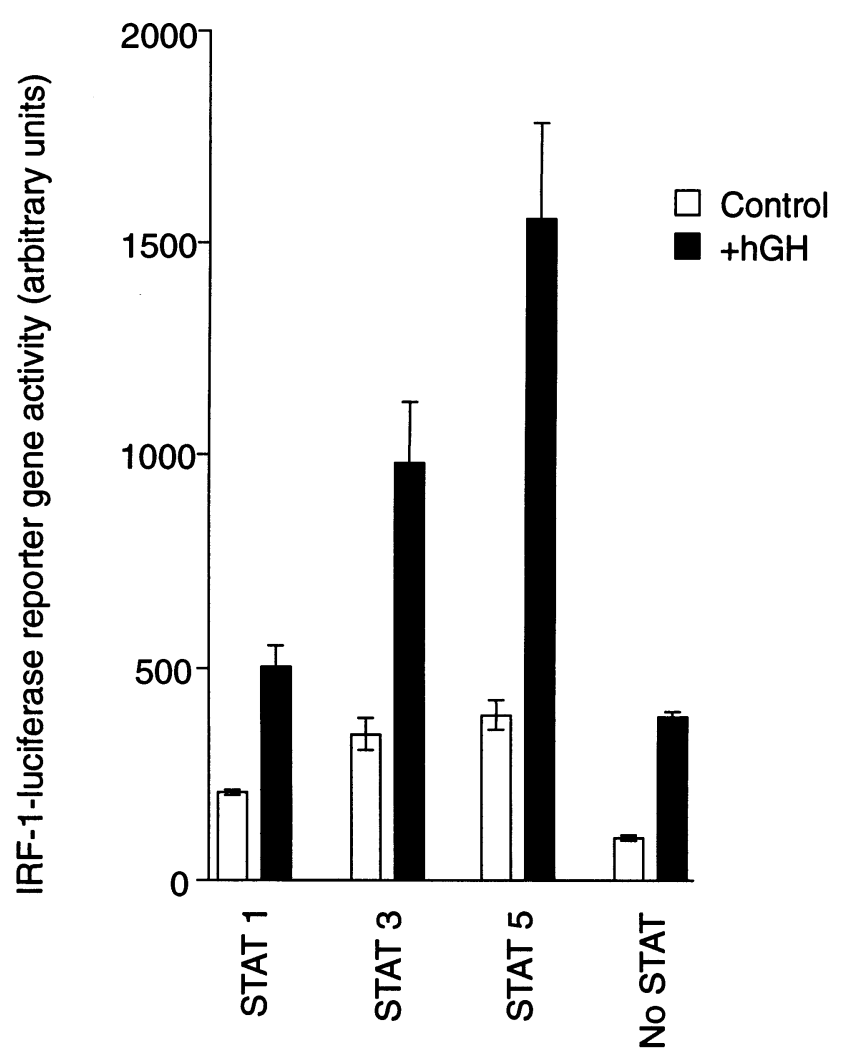

Fig. 4. COS 7 cells were transfected with the pB2WT2 (IRF-1) luciferase reporter plasmid, pRc-CMV-CAT normalisation control plasmid, a cDNA expression plasmid for the rat growth hormone receptor and cDNA expression plasmids for mouse STAT 1, mouse STAT 3 or sheep STAT 5. The cells were treated, as indicated, with $100 \mathrm{nM}$ human growth hormone for $24 \mathrm{~h}$ and then harvested for reporter gene assays. Values shown represent normalised luciferase activities in arbitrary units. Each column represents the average of three independent experiments. Error bars represent S.D.

\subsection{Activation of STAT 5 by truncated growth hormone receptors}

The activation of STAT 3 by several cytokine receptors is facilitated by the presence of specific tyrosine residues in the receptor intracellular domain (Stahl et al., 1995). In addition STAT 6 has been shown to bind directly to the interleukin-4 receptor via a phosphorylated receptor tyrosine (Hou et al., 1994). The intracellular domain of the rat growth hormone receptor contains ten tyrosine residues each of which could act as a specific STAT docking site (Fig. 6). In order to investigate the role of the membrane distal growth hormone receptor domain in the activation of STAT 5 , cDNA expression plasmids expressing the 638 amino acid wild type receptor or mutants truncated at amino acids $295,380,455$ or 540 were transiently co-transfected into COS 7 cells together with a cDNA expression plasmid for STAT 5 and the pSPI-LUC reporter plasmid. The results shown in Fig. 7 illustrate that receptors truncated at amino acid 380 or 455 were capable of activating STAT 5, although the efficiency of activation was significantly reduced. Deletion of the entire intracellular domain of the growth hormone re-
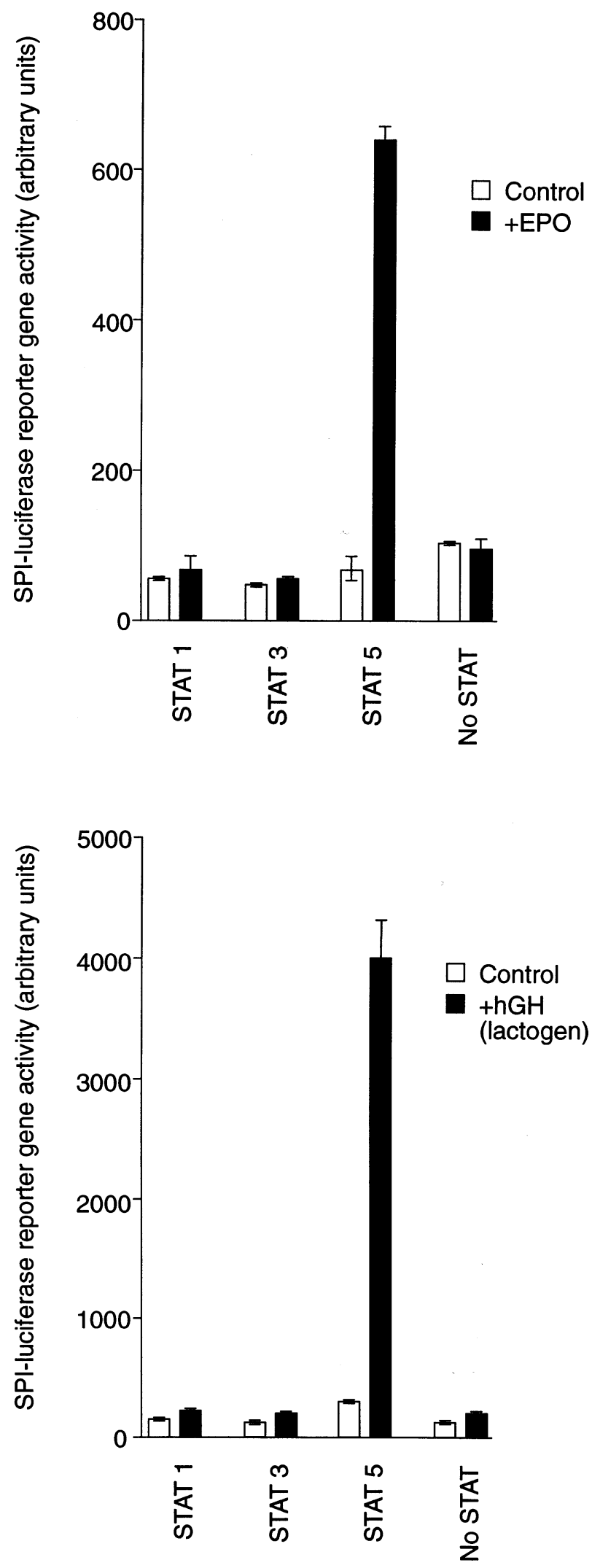

Fig. 5. 


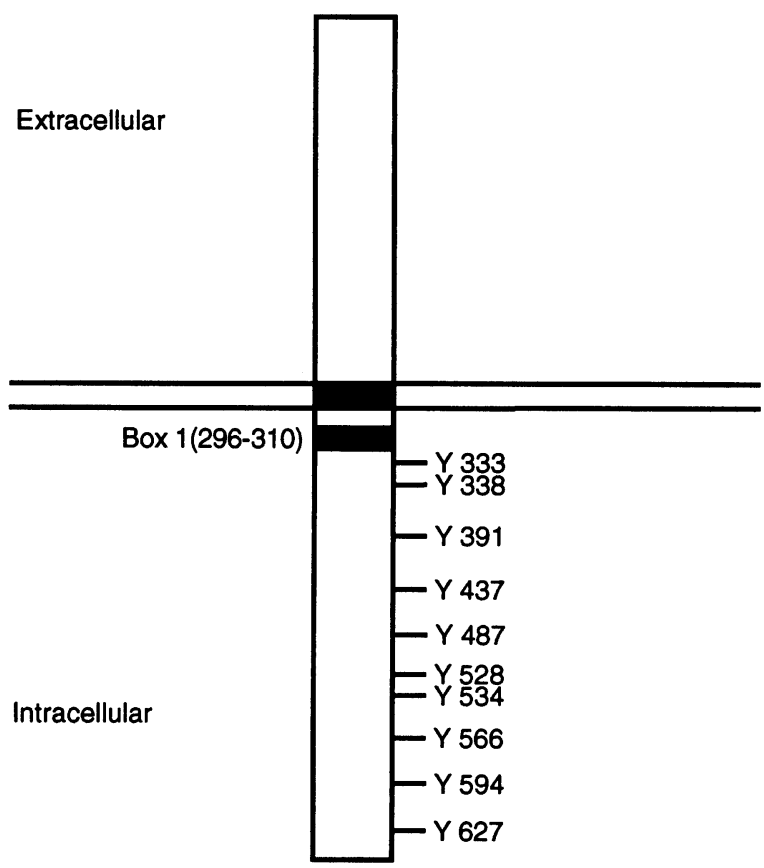

Fig. 6. Cartoon of the rat growth hormone receptor showing intracellular tyrosine residues and Box 1.

ceptor (i.e. truncation at amino acid 295) abolished the ability of the receptor to transduce signals via STAT 5 , as expected. The specific binding of iodinated human growth hormone to COS 7 cells which had been transiently transfected with wild type or mutated growth hormone receptor cDNAs is shown in Fig. 8. The transfection of all of the receptor cDNAs resulted in binding of labelled human growth hormone to cells. The reduced binding of the 380 STOP receptor construct has been observed previously, both in cells transiently and stably expressing the 380 STOP cDNA (Wood et al., unpublished observation). As can be seen in Fig. 6 the rat growth hormone receptor contains six tyrosine residues between amino acid 455 and the C-terminus. The results shown in Fig. 7 suggest that at least one of these is involved in determining the level of STAT 5 activation. However, as can be seen in Fig. 9 point mutation of these tyrosines had no significant effect on receptor signalling. The region of the receptor between the membrane and amino acid 380, which was

Fig. 5. COS 7 cells were transfected with the pSPI-LUC luciferase reporter plasmid, pRc-CMV-CAT normalisation control plasmid, cDNA expression plasmids for the mouse prolactin or erythropoietin receptor and cDNA expression plasmids for mouse STAT 1, mouse STAT 3 or sheep STAT 5. The cells were treated for $24 \mathrm{~h}$ with 100 $\mathrm{nM}$ human growth hormone or $4 \mathrm{U} / \mathrm{ml}$ erythropoietin, as indicated, and then harvested for reporter gene assays. Human growth hormone binds to the mouse prolactin receptor with high affinity (Shiu, 1979). Values shown represent normalised luciferase activities in arbitrary units. Each column represents the average of three independent experiments. Error bars represent S.D.

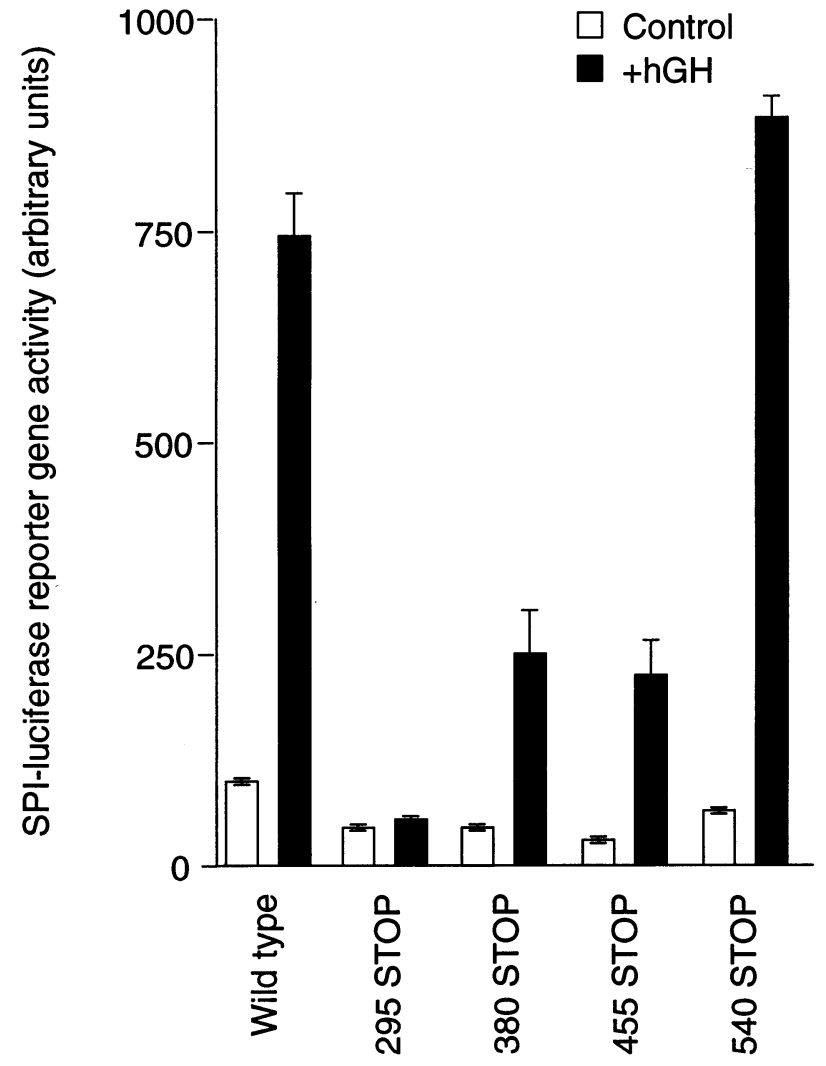

Fig. 7. COS 7 cells were transfected with the pSPI-LUC luciferase reporter plasmid, pRc-CMV-CAT normalisation control plasmid, and cDNA expression plasmids for sheep STAT 5 and wild type rat growth hormone receptor cDNA or rat growth hormone receptor cDNA truncated at codon $295,380,455$ or 540 . The cells were treated, as indicated, with $100 \mathrm{nM}$ human growth hormone for $24 \mathrm{~h}$ and then harvested for reporter gene assays. Values shown represent normalised luciferase activities in arbitrary units. Each column represents the average of three independent experiments. Error bars represent S.D.

found to constitute a minimal STAT 5 activation domain contains two tyrosines. Point mutation of both of these also had no significant effect on receptor signalling. Since the receptor mutants truncated at amino acids 455 and 380 show essentially the same signalling capacity it is unlikely that tyrosines 391 and 437 play a role in STAT 5 activation.

\subsection{Activation of gene expression via STAT responsive elements by sodium orthovanadate}

It has been reported that sodium orthovanadate can prevent the inactivation of STAT $1 \alpha$ DNA binding induced by prolonged interferon treatment, and that sodium pervanadate can simulate interferon $\gamma$ induced phosphorylation of JAK 1 , JAK 2, STAT $1 \alpha$ and the interferon $\gamma$ receptor (Igarashi et al., 1994). These studies indicate that, by non-specifically inhibiting tyrosine phosphatases, vanadate ions cause an increase in the level of cellular protein tyrosine phosphorylation, and 
that this could serve as a useful tool in the investigation of signal transduction. COS 7 cells were therefore transfected with an expression plasmid for STAT 5 and the pSPI-LUC reporter plasmid, and then treated with 1 $\mathrm{mM}$ sodium orthovanadate for $24 \mathrm{~h}$. As can be seen in Fig. 10 sodium orthovanadate was clearly able to activate SPI-LUC reporter gene expression in STAT 5 transfected cells. The STAT specificity of reporter gene expression was identical to that seen following growth hormone treatment. It should be noted that the cells in this experiment were not transfected with receptor cDNA. As can be seen in Fig. 11 sodium orthovanadate was also found to activate STATs 1 and 3 when a broad specificity STAT responsive element, in this case from the IRF-1 promoter, is present in the reporter plasmid.

\subsection{JAK 2 binds directly to STAT 5 following sodium orthovanadate treatment of cells}

JAK 2 has been reported to phosphorylate and thereby activate the DNA binding capacity of in vitro translated STAT 5 (Gouilleux et al., 1994). We wished to determine whether JAK 2 and STAT 5 were capable

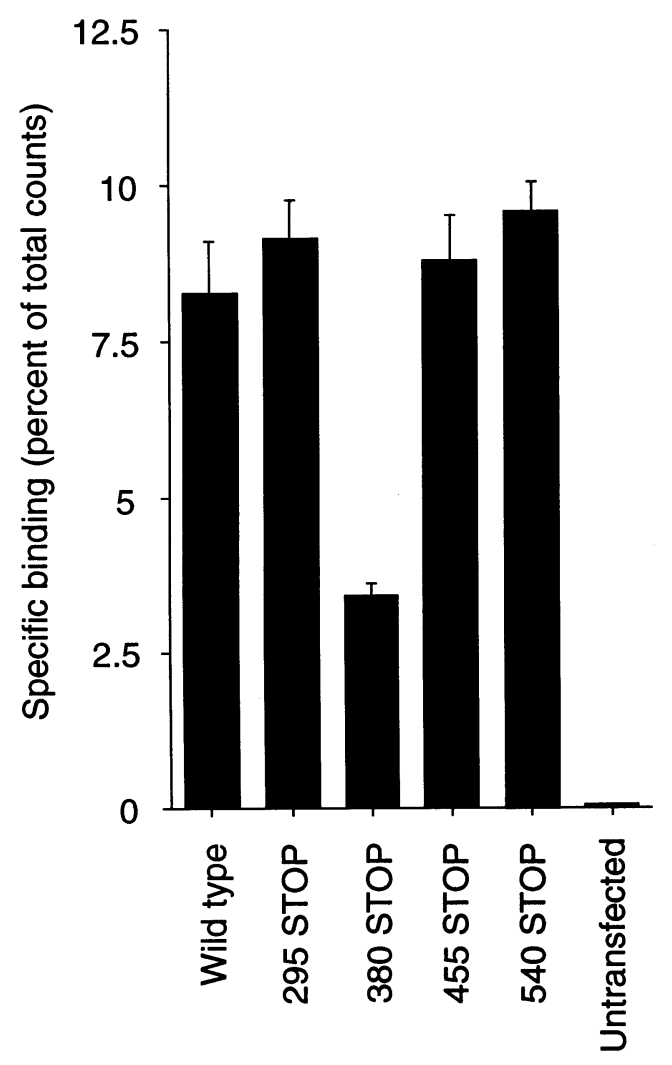

Fig. 8. COS 7 cells were transfected as in Fig. 7 and after $12 \mathrm{~h}$ exposed to iodinated human growth hormone $(100000 \mathrm{cpm})$ in the presence or absence of an excess of unlabelled human growth hormone $(1000 \mathrm{nM})$. Specific binding is shown as a proportion of total added radioactivity.

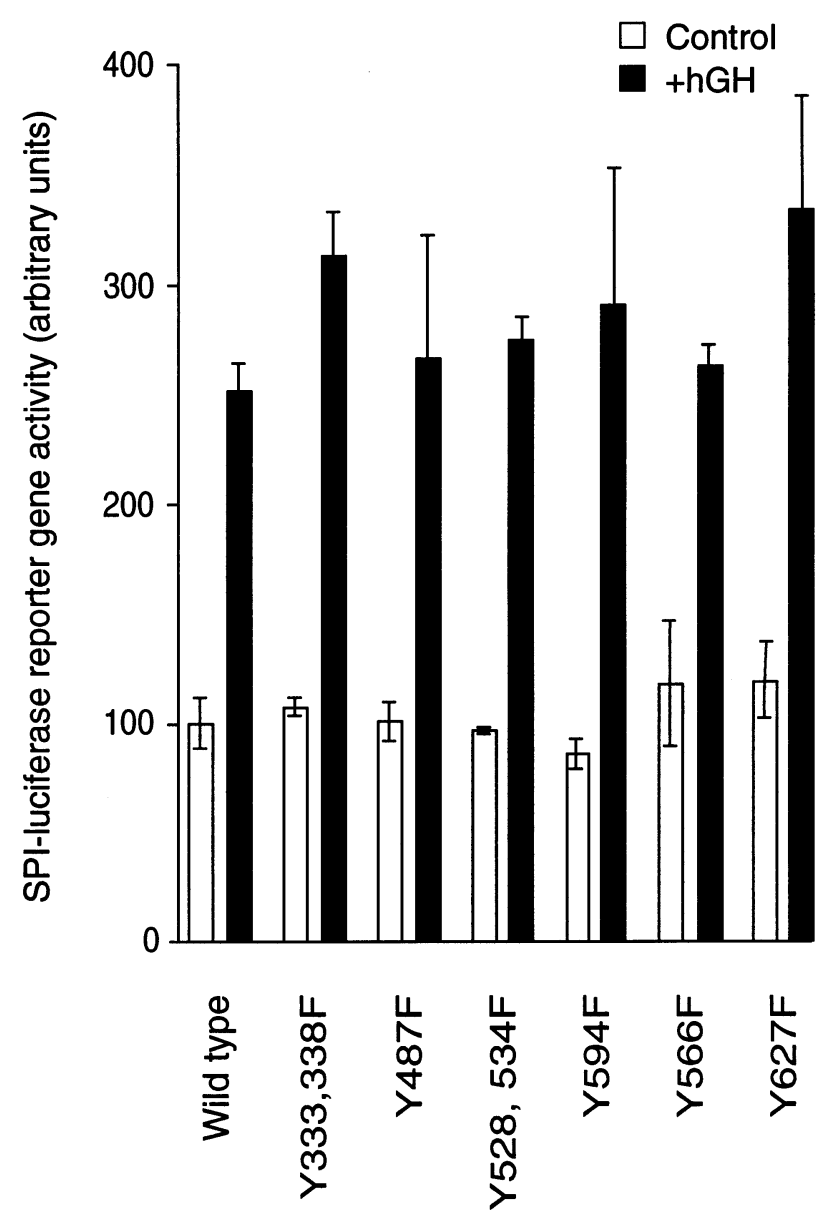

Fig. 9. COS 7 cells were transfected with the pSPI-LUC luciferase reporter plasmid, pRc-CMV-CAT normalisation control plasmid, and cDNA expression plasmids for sheep STAT 5 and wild type rat growth hormone receptor cDNA or rat growth hormone receptor cDNA containing tyrosine to phenylalanine point mutations, as indicated. The cells were treated, as indicated, with $100 \mathrm{nM}$ human growth hormone for $24 \mathrm{~h}$ and then harvested for reporter gene assays. Values shown represent normalised luciferase activities in arbitrary units. Each column represents the average of three independent experiments. Error bars represent S.D.

of physical association in cultured cells. COS 7 cells were therefore transfected with a cDNA encoding an HA (influenza hemagglutin A) epitope tagged STAT 5. The HA epitope tag allowed the ready precipitation of the transfected STAT 5. Whole cell extracts were prepared from the transfected COS 7 cells which had been treated with $1 \mathrm{mM}$ sodium orthovanadate for $4 \mathrm{~h}$. STAT 5 was then immunoprecipitated with the HA epitope specific antibody and the presence of STAT 5 and co-immunoprecipitated JAK 2 or JAK 1 was determined by Western blot analysis. As can be seen in Fig. 12 a faint band at $130 \mathrm{kDa}$ corresponding to JAK 2 was observed in extracts from vehicle treated cells. However, the intensity of this band was markedly increased in sodium orthovanadate treated cells which is consistent with a sodium orthovanadate induced association of JAK 2 with STAT 5. STAT 5 immunoprecipi- 
tates were also subjected to Western blot analysis for JAK 1. No sodium orthovanadate induced association of STAT 5 with JAK 1 was observed. This indicates that the immunoprecipitation conditions used were appropriate for observation of a specific association between JAK 2 and STAT 5.

\section{Discussion}

Considerable progress has been made in elucidating the signal transduction mechanisms employed by the cytokine receptors. It is now possible to hypothesise a working model for the cytokine dependent transcriptional activation of a number of genes. Hormone binding leads to activation of members of the JAK family of protein tyrosine kinases. This is followed by phosphorylation of both the kinase and the associated receptor. A variety of intracellular signalling molecules then bind to the phosphorylated receptor and become available as substrates for the activated JAK molecule. These signalling molecules include members of the STAT family

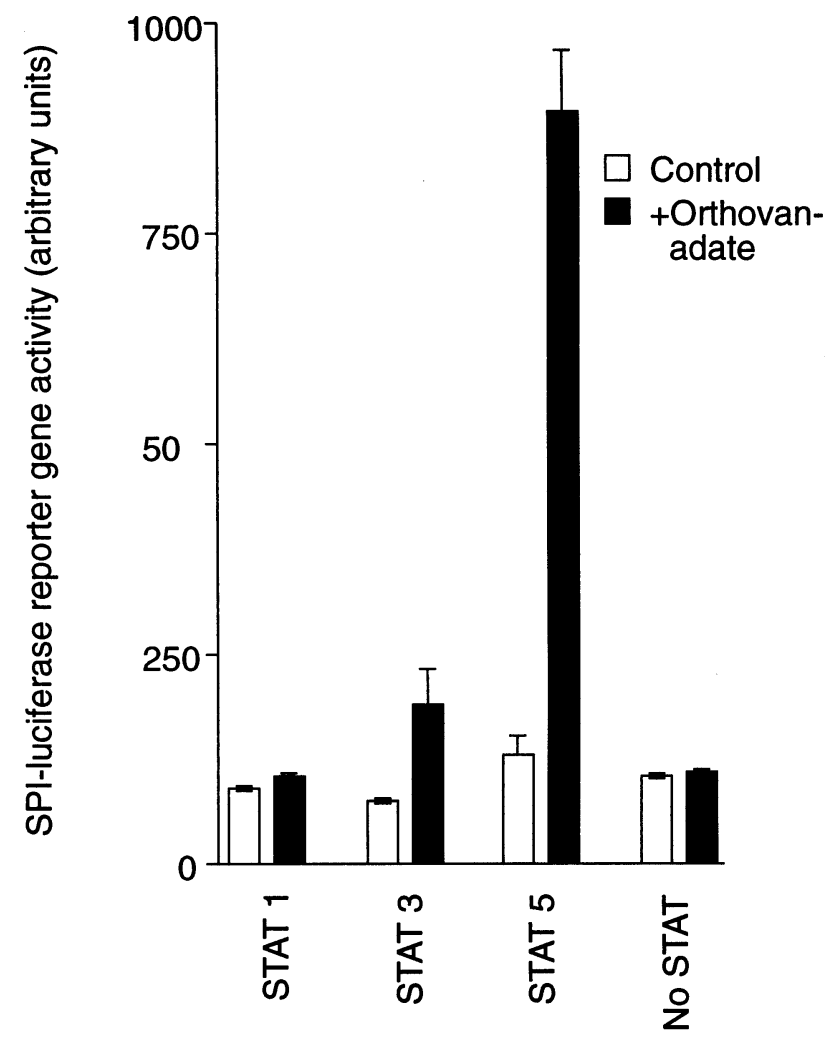

Fig. 10. COS 7 cells were transfected with the pSPI-LUC luciferase reporter plasmid, pRc-CMV-CAT normalisation control plasmid and cDNA expression plasmids for sheep STAT 5 or mouse STATs 1 or 3 . The cells were treated, as indicated, with $1 \mathrm{mM}$ sodium orthovanadate for $24 \mathrm{~h}$ and then harvested for reporter gene assays. Values shown represent normalised luciferase activities in arbitrary units. Each column represents the average of three independent experiments. Error bars represent S.D.

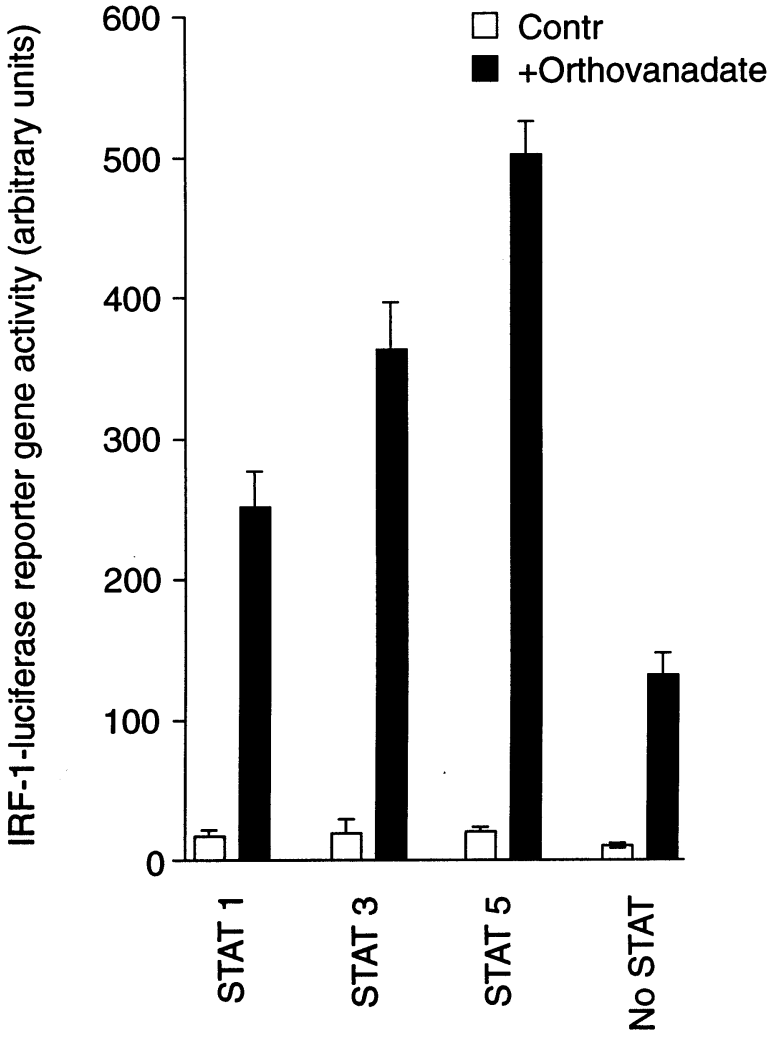

Fig. 11. COS 7 cells were transfected with the pIRF-1-LUC luciferase reporter plasmid: pRc-CMV-CAT normalisation control plasmid and cDNA expression plasmids for sheep STAT 5 or mouse STATs 1 or 3 . The cells were treated, as indicated, with $1 \mathrm{mM}$ sodium orthovanadate for $24 \mathrm{~h}$ and then harvested for reporter gene assays. Values shown represent normalised luciferase activities in arbitrary units. Each column represents the average of three independent experiments. Error bars represent S.D.

of DNA binding transcription enhancers. Following their phosphorylation on tyrosine residues STATs form homo or heterodimers (Shuai et al., 1994), presumably as a result of phosphotyrosine-SH 2 domain association. This dimerization is accompanied by nuclear transport (Decker et al., 1991), DNA binding to specific STAT response elements and stimulation of gene transcription.

In this report we have investigated several aspects of the specificity of the STAT response element present in the growth hormone regulated serine protease inhibitor (SPI) 2.1 promoter. The results show that the SPI 2.1 STAT responsive element shows preference for STAT 5 and does not respond to STATs 1 or 3, although all three of these STATs are activated by growth hormone treatment of cells. We also show that the ligand bound prolactin and erythropoietin receptors enhance gene transcription via STAT 5 binding to the SPI STAT response element.

The SPI 2.1 gene is expressed principally in the liver. It is not expressed in a variety of other tissues expressing receptors for growth hormone, nor is its expression 
stimulated by other cytokines, such as prolactin, which are capable of activating STAT 5 (Warren et al., 1993). In addition to the region containing the STAT responsive element the SPI 2.1 promoter has been shown to contain other growth hormone responsive regions (Le-Cam et al., 1994). It is possible that these must be activated simultaneously, or according to a growth hormone specific temporal pattern, in order to confer growth hormone responsiveness on SPI 2.1 expression. Alternatively the expression of the SPI 2.1 gene may be more strongly repressed in non-hepatic tissues than in the liver. Other signalling pathways, such as those leading to serine phosphorylation of STATs (Zhang et al., 1995; Eilers et al., 1995), may also have a role in maintaining tissue specific expression of the SPI 2.1 gene. Interestingly the serine protease inhibitor 2.3 gene which shows extensive homology with the serine protease inhibitor 2.1 gene has a $42 \mathrm{bp}$ insertion close to the STAT response element. In addition, the STAT responsive element equivalent to SPI-GLE 1 contains a number of base substitution which make it responsive both STATs 3 and 5B (Kordula et al., 1996). This demonstrates that minor changes in the sequence of STAT response elements can have profound effects on their physiology.

The activation of STAT 3 and STAT 6 by cytokine receptors has been shown to be facilitated by the presence of specific phosphorylated receptor tyrosine residues (Hou et al., 1994; Stahl et al., 1995). This has

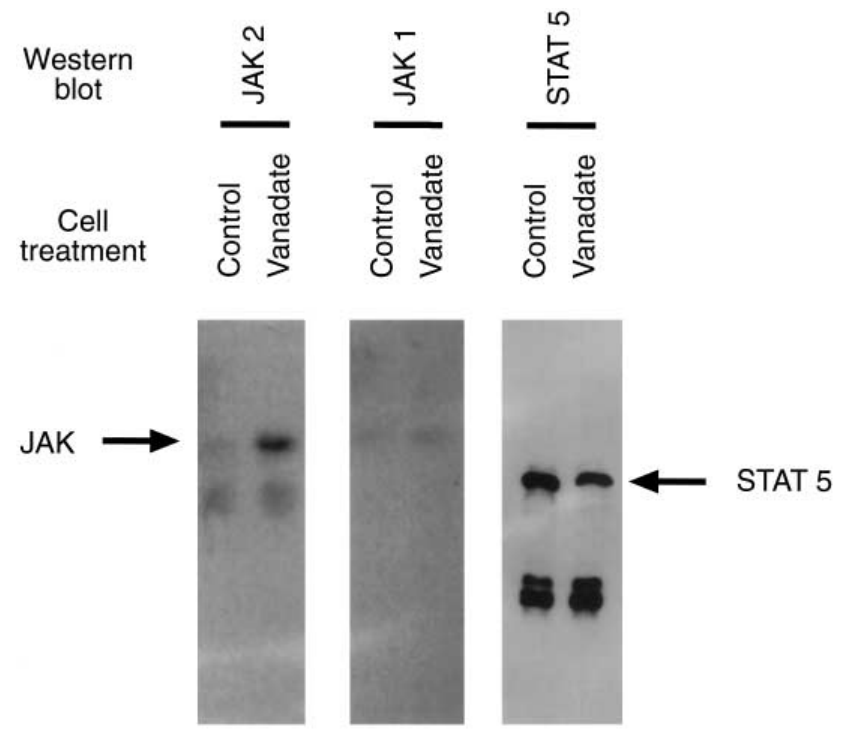

Fig. 12. COS 7 cells were transiently transfected with HA epitope tagged STAT5 cDNA as described. The cells were then treated with vehicle or $1 \mathrm{mM}$ sodium orthovanadate for $4 \mathrm{~h}$. Whole cell extracts were prepared and immunoprecipitated with anti HA 12CA5 antibody (1:1000 dilution) and protein $\mathrm{G}$. The immunoprecipitated material was divided into three identical aliquots and analysed as follows: (i) Western blot with anti JAK 2 antibodies; (ii) Western blot with anti JAK 1 antibodies; (iii) Western blot with anti STAT 5 antibodies. been suggested to confer receptor specificity on the activation of these STATs. However, the data concerning the role of growth hormone receptor tyrosine residues in activation of gene transcription via STAT 5 is somewhat contradictory. Wang et al. and Hacket et al. have shown that a human growth hormone receptor truncation mutant, equivalent to the 380 STOP mutant used here but containing no tyrosine residues, activated STAT DNA binding in gel electrophoresis mobility shift assays (Wang et al., 1995a,b and Hackett et al., 1995). Goujon et al., Sotiropoulos et al. and Hansen et al. have, on the other hand, reported that a rat growth hormone receptor truncation mutant corresponding to the 455 STOP mutant used here, failed to stimulate the activation of a CAT reporter gene containing the SPI-GHRE (Hansen et al., 1996; Goujon et al., 1994; Sotiropoulos et al., 1994). Furthermore, Hansen et al. observed that at least one of the receptor tyrosines 534, 566 or 627 are required for reporter gene activation. Smit et al. used STAT 5 phosphorylation as an assay for signalling by receptor mutants, and found that a rat growth hormone receptor truncation mutant corresponding to the 455 STOP mutant transduced signals weakly, and that a similar mutant lacking tyrosines was inactive (Smit et al., 1996). Finally, Frank et al. have reported that a chimera consisting of the extracellular and transmembrane domains of the growth hormone receptor fused to JAK 2 tranduces signals via STATs (Frank et al., 1995).

The results presented here indicate that the membrane proximal region of the growth hormone receptor, which contains the conserved Box 1 motif (amino acids 296-310) required for association with JAK 2 (Frank et al., 1994), is sufficient for activation of STAT 5. This region contains two tyrosine residues (333 and 338) which could act as STAT 5 docking sites. However, point mutation of these tyrosines to phenylalanines in the full length receptor had no significant effect on activation of STAT 5. That the growth hormone receptor mutants truncated at amino acids 455 and 380 activated SPI-LUC expression significantly less efficiently than the full length receptor indicates that tyrosines residues in the receptor C-terminus normally play a role in STAT 5 activation. However, point mutation of these tyrosines to phenylalanines also had no significant effect on activation of STAT 5. Thus it is likely that several phosphorylated tyrosine residues in the growth hormone receptor can potentially act as docking sites for STAT 5 .

The results of the experiments involving sodium orthovanadate treatment of cells and reporter gene assays or immunoprecipitation indicate that STAT 5 can form a complex with activated JAK 2 in the absence of ligand activated receptor. Sodium orthovanadate treatment of cells results in the phosphorylation of a 
large number of proteins including JAK 2, and STATs 1,3 and 5. Although it cannot be considered a physiological stimulus treatment of cells with vanadate ions provides a useful tool for the study of phosphotyrosine-SH 2 domain interactions. We have also observed the formation of a complex between activated JAK 2 purified from growth hormone treated rat liver cells by immunoprecipitation and STAT 5 expressed using the baculovirus system (Flores et al., unpublished observation). That STAT 5 and activated JAK 2 form an substrate-enzyme complex, in the absence of ligand activated receptors, leads to the hypothesis that phosphorylated tyrosine residues on JAK 2 may provide docking sites for STATs in activated cytokine receptor-JAK 2 signalling complexes. This may explain why growth hormone receptors containing no or very few tyrosine residues maintain a residual level of STAT activation (Hackett et al., 1995; Wang et al., 1995a,b). It may also explain why a chimera consisting of the extracellular and transmembrane domains of the growth hormone receptor fused to JAK 2 tranduces signals via STATs (Frank et al., 1995). The evidence presented here, taken together with previously published work, suggests the existence of two potential pathways leading to growth hormone induced phosphorylation of STAT 5. STAT 5 may first bind to phosphorylated tyrosine residues $333 / 338,534$, 566 or 627 in the receptor intracellular domain and then migrate to the JAK 2 binding region. Alternatively it may associate with JAK 2 directly, following ligand binding to the receptor. Although these mechanisms may operate in parallel the former appears to be more efficient. That receptor tyrosine residues in a variety of amino acid contexts, or phosphorylated JAK 2 alone, can facilitate STAT 5 activation could explain the observed lack of cytokine specificity in STAT 5 activation.

In conclusion, the work presented here demonstrates for the first time a clear STAT 5 specificity in the enhancement of gene transcription via the STAT response element in the SPI promoter. It also demonstrates that a variety of cytokines can utilise this signal transduction pathway. This data was derived using a transfected reporter gene assay rather than the ubiquitous gel electrophoresis mobility shift assay. Quantitative differences in the activation of different signal transduction pathways appear to be important to the mechanism of enhancement of gene transcription via the STATs. Reporter assays allow the quantitation of the effect of variables, such as the activating cytokine and the sequence of the response element in STAT signalling, in a semi-physiological setting. They are therefore likely to play an important role in future investigations.

\section{Acknowledgements}

Supported by grants from the Swedish Medical Research Council (grant number 8556), the Swedish Cancer Society (grant number 3020 B94 02XBB), the Swedish Medical Association, the Czech Grant Agency (grant number 505/93/1134) and Pharmacia and Upjohn. The anti JAK 1 antibody was a gift from Dr Andrew Zeimeicki. The plasmid pB2WT2 was a gift from Dr Chris Schindler. The expression vectors containing mutated rat growth hormone receptor cDNAs were a gift from Dr Nils Billestrup. The mouse erythropoietin receptor cDNA expression plasmid was a gift from Dr Harvey Lodish.

\section{References}

Akira, S., Nishio, Y., Inoue, M., Wang, X.J., Wei, S., Matsusaka, T., Yoshida, K., Sudo, T., Naruto, M., Kishimoto, T., 1994. Molecular cloning of APRF, a novel IFN-stimulated gene factor 3 p91-related transcription factor involved in the gpl30-mediated signaling pathway. Cell 77, 63-71.

Argetsinger, L.S., Campbell, G.S., Yang, X., Witthuhn, B.A., Silvennoinen, O., Ihle, J.N., Carter-Su, C., 1993. Identification of JAK 2 as a growth hormone receptor-associated tyrosine kinase. Cell 74, 237-244.

Berry, S.A., Bergad, P.L., Whaley, C.D., Towle, H.C., 1994. Binding of a growth hormone-inducible nuclear factor is mediated by tyrosine phosphorylation. Mol. Endocrinol. 8, 1714-1719.

Decker, T., Lew, D.J., Mirkovitch, J., Darnell, J. Jr., 1991. Cytoplasmic activation of GAF, an IFN- $\gamma$-regulated DNA-binding factor. EMBO J. 10, 927-932.

Eilers, A., Georgellis, D., Klose, B., Schindler, C., Ziemiecki, A., Harpur, A.G., Wilks, A.F., Decker, T., 1995. Differentiation-regulated serine phosphorylation of STAT1 promotes GAF activation in macrophages. Mol. Cell. Biol. 15, 3579-3586.

Finbloom, D.S., Petricoin, E.R., Hackett, R.H., David, M., Feldman, G.M., Igarashi, K., Fibach, E., Weber, M.J., Thorner, M.O., Silva, C.M., Lamer, A.C., 1994. Growth hormone and erythropoietin differentially activate DNA-binding proteins by tyrosine phosphorylation. Mol. Cell. Biol. 14, 2113-2118.

Frank, S.J., Gilliland, G., Kraft, A.S., Arnold, C.S., 1994. Interaction of the growth hormone receptor cytoplasmic domain with the JAK 2 tyrosine kinase. Endocrinology 135, 2228-2239.

Frank, S.J., Yi, W., Zhao, Y., Goldsmith, J.F., Gilliland, G., Jiang, J., Sakai, I., Kraft, A.S., 1995. Regions of the JAK 2 tyrosine kinase required for coupling to the growth hormone receptor. J. Biol. Chem. 270, 14776-14785.

Fu, X.Y., Schindler, C., Improta, T., Aebersold, R., Darnell, J., 1992. The proteins of ISGF-3, the interferon $\alpha$-induced transcriptional activator, define a gene family involved in signal transduction. Proc. Natl. Acad. Sci. USA 89, 7840-7843.

Gouilleux, F., Wakao, H., Mundt, M., Groner, B., 1994. Prolactin induces phosphorylation of Tyr694 of Stat 5 (MGF), a prerequisite for DNA binding and induction of transcription. EMBO J. 13, 4361-4369.

Goujon, L., Allevato, G., Simonin, G., Paquereau, L., Le-Cam, A., Clark, J., Nielsen, J.H., Djiane, J., Postel-Vinay, M.C., Edery, M., Kelly, P.A., 1994. Cytoplasmic sequences of the growth hormone receptor necessary for signal transduction. Proc. Natl. Acad. Sci. USA 91, 957-961. 
Gronowski, A.M., Rotwein, P., 1994. Rapid changes in nuclear protein tyrosine phosphorylation after growth hormone treatment in vivo. Identification of phosphorylated mitogen-activated protein kinase and STAT91. J. Biol. Chem. 269, 7874-7878.

Hackett, R.H., Wang, Y.D., Larner, A.C., 1995. Mapping of the cytoplasmic domain of the human growth hormone receptor required for the activation of JAK 2 and STAT proteins. J. Biol. Chem. 270, 21326-21330.

Hansen, L.H., Wang, X., Kopchick, J.K., Bouchelouche, P., Nielsen, J.H., Galsgaard, E.D., Billestrup, N., 1996. Identification of tyrosine residues in the intracllular domain of the growth hormone receptor required for transcriptional signalling and STAT 5 activation. J. Biol. Chem. 271, 12669-12673.

Hou, J., Schindler, U., Henzel, W.J., Ho, T.C., Brasseur, M., McKnight, S.L., 1994. An interleukin-4-induced transcription factor: IL-4 STAT. Science 265, 1701-1706.

Igarashi, K., Garotta, G., Ozmen, L., Ziemiecki, A., Wilks, A.F., Harpur, A.G., Larner, A.C., Finbloom, D.S., 1994. Interferon- $\gamma$ induces tyrosine phosphorylation of interferon- $\gamma$ receptor and regulated association of protein tyrosine kineses, Jakl and JAK 2, with its receptor. J. Biol. Chem. 269, 14333-14336.

Ihle, J.N., Kerr, I.M., 1995. Jaks and Stats in signaling by the cytokine receptor superfamily. Trends Genet. 11, 69-74.

Kordula, T., Ripperger, J., Morell, K.K., Travis, J., Baumann, H., 1996. Two separate signal transducer and activator of transcription proteins regulate transcription of the serine protease inhibitor-3 gene in hepatic cells. J. Biol. Chem. 271, 6752-6757.

Le-Cam, A., Pages, G., Auberger, P., Le-Cam, G., Leopold, P., Benarous, R., Glaichenhaus, N., 1987a. Study of a growth hormone regulated protein secreted by rat hepatocytes: cDNA cloning, anti-protease activity and regulation of its synthesis by various hormones. EMBO J. 6, 1225-1232.

Le-Cam, G., Le-Cam, A., 1987b. Synthesis of the growth hormone regulated rat liver anti-protease GHR-P63 is inhibited by acute inflammation. FEBS. Lett. 210, 1-5.

Le-Cam, A., Pantescu, V., Paquereau, L., Legraverend, C., Fauconnier, G., Asins, G., 1994. cis-Acting elements controlling transcription from rat serine protease inhibitor 2.1 gene promoter. Characterization of two growth hormone response sites and a dominant purine-rich element. J. Biol. Chem. 269, 21532-21539.

Liu, X., Robinson, G.W., Gouilleux, F., Groner, B., Hennighausen, L., 1995. Cloning and expression of Stat5 and an additional homologue (Stat $5 \mathrm{~b}$ ) involved in prolactin signal transduction in mouse mammary tissue. Proc. Natl. Acad. Sci. USA 92, 88318835.

Meyer, D.J., Campbell, G.S., Cochran, B.H., Argetsinger, L.S., Larner, A.C., Finbloom, D.S., Carter-Su, C., Schwartz, J., 1994. Growth hormone induces a DNA binding factor related to the interferon-stimulated $91-\mathrm{kDa}$ transcription factor. J. Biol. Chem. 269, 4701-4704.

O’Neal, K.D., Yu-Lee, L.Y., 1994. Differential signal transduction of the short, $\mathrm{Nb} 2$, and long prolactin receptors. Activation of interferon regulatory factor- 1 and cell proliferation. J. Biol. Chem. 269, 26076-26082.

Schindler, C., Fu, X.Y., Improta, T., Aebersold, R., Darnell, J. Jr., 1992. Proteins of transcription factor ISGF-3: one gene encodes the 91 and $84-\mathrm{kDa}$ ISGF-3 proteins that are activated by interferon $\alpha$. Proc. Natl. Acad. Sci USA. 89, 7836-7839.

Shiu, R.P., 1979. Prolactin receptors in human breast cancer cells in long-term tissue culture. Cancer Res. 39, 4381-4386.

Shuai, K., Horvath, C.M., Huang, L.H., Qureshi, S.A., Cowburn, D., Darnell, J. Jr., 1994. Interferon activation of the transcription factor Stat91 involves dimerization through SH2-phosphotyrosyl peptide interactions. Cell 76, 821-828.

Schwarz, L.A., Stevens, A.M., Hrachovy, J.A., Yu-Lee, L.Y., 1992. Interferon regulatory factor- 1 is inducible by prolactin, interleukin-2 and concanavalin A in T cells. Mol. Cell. Endocrinol. 86, $103-110$.
Silva, C.M., Weber, M.J., Thorner, M.O., 1993. Stimulation of tyrosine phosphorylation in human cells by activation of the growth hormone receptor. Endocrinology 132, 101-108.

Sliva, D., Wood, T.J., Schindler, C., Lobie, P.E., Norstedt, G., 1994. Growth hormone specifically regulates serine protease inhibitor gene transcription via $\gamma$-activated sequence-like DNA elements. J. Biol. Chem. 269, 26208-26214.

Smit, L., Meyer, D.J., Billestrup, N., Norstedt, G., Schwartz, J., Carter-Su, C., 1996. The Role of the Growth Hormone (GH) Receptor and JAK 1 and JAK 2 Kinases in the Activation of Stats 1,3 and 5 by GH. Mol. Endocrinol. 10, 519-533.

Sotiropoulos, A., Perrot, M.A., Dinerstein, H., Pallier, A., Postel, M.C.V., Finidori, J., Kelly, P.A., 1994. Distinct cytoplasmic regions of the growth hormone receptor are required for activation of JAK 2, mitogen-activated protein kinase, and transcription. Endocrinology 135, 1292-1298.

Stahl, N., Farruggella, T.J., Boulton, T.G., Zhong, Z., Darnell, J. Jr., Yancopoulos, D., 1995. Choice of STATs and other substrates specified by modular tyrosine-based motifs in cytokine receptors. Science 267, 1349-1353.

Thomas, M.J., Gronowski, A.M., Berry, S.A., Bergad, P.L., Rotwein, P., 1995. Growth hormone rapidly activates rat serine protease inhibitor 2.1 gene transcription and induces a DNA-binding activity distinct from those of Statl, -3, and -4. Mol. Cell. Biol. 15, $12-18$.

Tsukada, J., Waterman, W.R., Koyama, Y., Webb, A.C., Auron, P.E., 1996. A novel STAT-like factor mediates lipopolysaccharide, interleukin 1 (IL-1), and IL-6 signaling and recognizes a gamma interferon activation site-like element in the IL1B gene. Mol. Cell. Biol. 16, 2183-2194.

Wakao, H., Gouilleux, F., Groner, B., 1994. Mammary gland factor (MGF) is a novel member of the cytokine regulated transcription factor gene family and confers the prolactin response. EMBO J. 13, 2182-2191.

Wang, Y.D., Wong, K., Wood, W.I., 1995a. Amino acids of the human growth hormone receptor that are required for proliferation and Jak-STAT signaling. Mol. Endocrinol. 9, 303-311.

Wang, Y.D., Wong, K., Wood, W.I., 1995b. Intracellular tyrosine residues of the human growth hormone receptor are not required for the signaling of proliferation or Jak-STAT activation. J. Biol. Chem. 270, 7021-7024.

Warren, W.C., Munie, G.E., Glenn, K.C., 1993. Spi-1: an hepatic serine protease inhibitor regulated by $\mathrm{GH}$ and other hormones. Mol. Cell. Endocrinol. 98, 27-32.

Wegenka, U.M., Lutticken, C., Buschmann, J., Yuan, J., Lottspeich, F., Muller-Esterl, W.E., Schindler, C., Roeb, E., Heinrich, P.C., Horn, F., 1994. The interleukin-6-activated acute-phase response factor is antigenically and functionally related to members of the signal transducer: and activator of transcription (STAT) family. Mol. Cell. Biol. 14, 3186-3196.

Wood, T.J., Sliva, D., Lobie, P.E., Pircher, T.J., Gouilleux, F., Wakao, H., Gustafsson, J.A., Groner, B., Norstedt, G., Haldosen, L.A., 1995. Mediation of growth hormone-dependent transcriptional activation by mammary gland factor/Stat 5 . J. Biol. Chem. 270, 9448-9453.

Yamamoto, K., Quelle, F.W., Thierfelder, W.E., Kreider, B.L., Gilbert, D.J., Jenkins, N.A., Copeland, N.G., Silvennoinen, O., Ihle, J.N., 1994. Stat4, a novel $\gamma$ interferon activation site-binding protein expressed in early myeloid differentiation. Mol. Cell. Biol. $14,4342-4349$.

Yan, R., Luo, H., Darnell, J. Jr., Dearolf, C.R., 1996a. A JAK STAT pathway regulates wing vein formation in Drosophila. Proc. Natl. Acad. Sci. USA 93, 5842-5847.

Yan, R., Small, S., Desplan, C., Dearolf, C.R., Darnell, J. Jr., 1996 b. Identification of a Stat gene that functions in Drosophila development. Cell 84, 421-430. 
Yuan, J., Wegenka, U.M., Lutticken, C., Buschmann, J., Decker, T., Schindler, C., Heinrich, P.C., Horn, F., 1994. The signalling pathways of interleukin-6 and $\gamma$ interferon converge by the activation of different transcription factors which bind to common responsive DNA elements. Mol. Cell. Biol. 14, 16571668 .
Zhang, X., Blenis, J., Li, H.C., Schindler, C., Chen-Kiang, S., 1995. Requirement of serine phosphorylation for formation of STAT-promoter complexes. Science 267, 1990-1994.

Zhong, Z., Wen, Z., Darnell, J. Jr., 1994. Stat 3: a STAT family member activated by tyrosine phosphorylation in response to epidermal growth factor and interleukin-6. Science 264, 95-98. 